Original Research Paper

\title{
Impact of Adopting Agricultural Technologies on Profitability and Production Practices of Tribal Farmers in Bangladesh
}

\author{
1,* Jasim Uddin Ahmed, ${ }^{2}$ Md. Abul Kashem, \\ ${ }^{1}$ Tabia Binte Shan, ${ }^{1}$ Prashanta Das and ${ }^{3}$ Md. Mosharraf Uddin Molla \\ ${ }^{1}$ Department of Agricultural Economics and Policy, Sylhet Agricultural University, Sylhet, Bangladesh \\ ${ }^{2}$ Department of Soil Science, Sylhet Agricultural University, Sylhet, Bangladesh \\ ${ }^{3}$ Agricultural Economics and Rural Sociology Division, Bangladesh Agricultural Research Council, Dhaka, Bangladesh
}

\author{
Article history \\ Received: 26-09-2020 \\ Revised: 15-11-2020 \\ Accepted: $30-11-2020$ \\ Corresponding Author: \\ Jasim Uddin Ahmed \\ Department of Agricultural \\ Economics and Policy, Sylhet \\ Agricultural University, Sylhet, \\ Bangladesh \\ Email: jahmed.sau@gmail.com
}

\section{Introduction}

Tribal people of Bangladesh are progenies of the true occupants of their land and are patently assorted in their way of life and patterns of social and economic association. Though the precise number of ethnic groups in Bangladesh is unidentified, but the government formally distinguishes 27 ethnic minorities. According to different right-based organizations, this number is more than 45 before the independence in 1971, but ethnic minorities claimed that the actual number might be 2 million (Barman and Neo, 2014). Bangladesh, in both hilly and plain areas, is furnished by traditional cultures of different tribal communities, e.g., the Mandi and Hajong, the Manipuri and Khasia, the Chakma, Marma, Rakhain, etc. and the Santal and Rajbangshi in the northern, northeast (Sylhet), eastern and southeastern and western parts of the country, respectively.

The sources of income for majority of the tribal people are below standard. In this region, most of the indigenous people earn their living through agricultural work and live just above or below the subsistence level. Though they earn their living through agricultural works, they have lack of knowledge about modern agricultural technologies. The other sources of household income of tribal people are livestock rearing, fish culture, selling of commodities and non-farm activities. It is possible for the tribal people of this region to improve the livelihood through integrated agricultural practices if they are provided with technical supports and modern technologies by the expert people. Since last couple of years, the attention government and international communities on the livelihoods of tribal 
clusters have increased, to ensure their socio-economic and cultural development mainly through enhancing tribal agriculture. For ensuring resourceful, productive and justifiable use of agricultural land, bringing food production self-sufficiency, improving nutritional status of ethnic population, New Agricultural Extension Policy (NAEP) has been launched by the government (MoA, 1996).

\section{Review of Existing Literature}

Melesse (2018) carried out a study to review the factors affecting adoption of agricultural new technologies like improved seed, pesticides, improved on farm storage techniques, methods of small-scale irrigation and fertilizer usage in Ethiopia. The authors found weak adoption of these technologies, which might be because of different socio-economic factors and the extent of risk aversion. Kassie et al. (2017) examined the determinants of farm households' participation in diversified nonagricultural income sources in Ethiopia and showed significant influence of institutional factors like secured perception of land ownership and cooperative membership. Begum (2015) assessed the impact of agricultural modernization on sustainable livelihood of the Santal community in West Bengal, India. The Santal of West Bengal is broadly known as an agriculturist tribe getting the benefit of agricultural modernization one way or other. Agricultural modernization had its impact in bringing about economic, social and cultural changes in their livelihood, still they live in a world of active seclusion and follow their own socio-cultural identity. Datta et al. (2014) found that Jhum or shifting cultivation is the dominant land-use practice of northeastern region of India, which is significantly affected by farmers' education, family size, farm area, income, extension participation, etc. The authors confirmed that Jhum cultivation has the potential of improving the livelihood status of tribal people.

Ahmmed (2012) studied on qualitative evidence from the Khasia and Garo communities of Bangladesh, focused on the problems of older people of these tribal groups and explained some of the coping mechanisms used by the elders. Findings indicated that high status and support is extended to elders by family and community as part of tribal tradition and culture. Nonetheless, these elders still face problems that are largely a function of their age and economic and social circumstances. Constraint in access to mainstream services is a major concern among the older Khasia and Garo people. The tribal older people experience negligence, exclusion and the violation of rights. Although the tribal older people have their own system to encounter problems, they are sensitive to the fact that their community does not always have the financial capacity to provide the required support. Nath et al. (2003) studied the socioeconomic and agricultural conditions of the Khasia tribe in Sylhet district of Bangladesh. The economy of the Khasia people is fundamentally forest-based. Betel leaf-based hill farming using traditional technology is their main source of occupation. The study revealed that this farming provides income and employment prospects in one hand and benefits in forest conservation and floral diversity in another hand. Kabir (2002) studied the participation of Garo youth in agricultural activities and revealed some problems as no adequate land for crop cultivation, no capital for crop cultivation, no contact with agricultural extension agencies, no training for modern vegetable cultivation and no update knowledge. In overall problem confrontation, above 75 percent of Garo youth had medium and non-fifth (14\%) had problem confrontation.

A few studies have been conducted on agricultural practices and livelihood of tribal farmers' in Bangladesh as tribal farmers live in remote areas. Therefore, research on agricultural practices of tribal people in this regions is critically important to know the situation of current agricultural practices among tribal people and their livelihood in order to provide them need based technical supports for modern agricultural practices to improve their living standard. This study will help to identify the factors affecting tribal farmers' decision to adopt agricultural technologies and its impact on agricultural production practices in Bangladesh.

\section{Materials and Methods}

\section{Survey of Study Areas, Sample Size and Tribal Groups}

Field survey method was conducted with the corresponding producers and different actors those who were involved with agricultural production, technology, inputs, labour utilization, distribution and consumption level. A total of 600 respondents were surveyed using multi-stage sampling technique. Three districts were selected from each of Sylhet and Chittagong division purposively as study areas which were: Sunamganj, Moulvibazar and Sylhet from Sylhet division and Rangamati, Bandarban and Khagrachari from Chittagong division. From each district, two upazilas were targeted based on the availability of the ethnic groups. From Sylhet division, Garo, Khasia and Manipuri gropus; and from Chittagong division, Chakma, Marma and Tanchang groups were interviewed. Higher priority was given to select the sampled villages considering the agricultural practices areas. All selected respondents were interviewed.

\section{Preparation of the Questionnaire and Data Collection}

The questionnaire was developed in accordance with the objectives of the research and before finalizing the questionnaire, the draft one was pre-tested. Validity and reliability of the questionnaire was also ensured. 
Information and data were collected from the respondents by using structured questionnaire. Secondary information relevant to this research were also collected from online and offline documents.

\section{Data Analysis}

To analyze the data, a combination of descriptive (i.e., sum, average, percentages, ratios, etc. with the support of tables and figures mentioned as field survey), mathematical and statistical techniques (mentioned as authors' estimation) were used.

Profitability of different agricultural enterprises under most common farming systems was measured in terms of gross return, gross margin, net return and benefit cost ratio (undiscounted). Gross return was calculated by multiplying the total volume of output of an enterprise by the average price in the harvesting period. The equation was as follows (Dillon and Hardaker, 1993):

$$
G R=X P_{X}+Y P_{Y}
$$

Where:

$X=$ Yield of main product per unit area

$P_{X}=$ Price of main product

$Y=$ Yield of by-product per unit area

$P_{Y}=$ Price of by-product

Gross margin was calculated by the difference between gross return and total variable cost. The following equation was used to calculate GM:

$$
G M=G R-T V C
$$

Where:

$G R=$ Gross return per unit area

$T V C=$ Total variable cost per unit area

Net return was calculated by deducting all costs (variable and fixed) from the gross return. The following algebraic form of NR was used for estimation:

$$
N R=G R-(T V C+T F C)
$$

Where:

$G R=$ Gross return per unit area

$T V C=$ Total variable cost per unit area

$T F C=$ Total fixed cost per unit area

Benefit Cost Ratio (BCR) is a relative measure which is used to compare the return per unit of cost. BCR was estimated as a ratio of gross return to gross cost. The formula used for calculating BCR (undiscounted) was as follows:

$$
B C R=G R \div G C
$$

Where:

$G R=$ Gross return per unit area

$G C=$ Gross cost per unit area (i.e., TVC + TFC)

The Enyedi's index was used to measure the crop productivity in the study areas compared to the entire regions (Ogale and Nagarale, 2014). For calculation, the following formula was used:

$$
\text { Crop productivity }=\left(Y T_{n} \div Y_{n} T\right) \times 100
$$

Where:

$Y=$ Production of the respective crop in the unit area

$Y_{n}=$ Total production of the crop in the entire region

$T=$ Cultivated unit area under the respective crop

$T_{n}=$ Cultivated area in the entire region under the respective crop

Inventory change of livestock was estimated as the difference between the inventory totals for the last reporting period and the current reporting period. Net change in inventory was calculated by deducting the sum of opening stock and bought from the sum of closing stock, consumed/gifted, sold and died. The formula used was as follows:

$$
\begin{aligned}
& \text { Net change in inventory } \\
& =(\text { Closing stock }+ \text { Consumed } / \text { gifted }+ \text { Sold }+ \text { Died }) \\
& -(\text { Opening stock }+ \text { Bought })
\end{aligned}
$$

To identify the level of influence of the factors influencing adoption of agricultural technologies by the farmers, the following logit model was used (Gujarati, 2003):

$$
\begin{aligned}
& Z_{i}=\ln \left[P_{i} \div\left(1-P_{i}\right)\right]=\beta_{0}+\beta_{1} Q_{1}+\beta_{2} Q_{2} \\
& +\beta_{3} Q_{3}+\beta_{4} Q_{4}+\beta_{5} Q_{5}+\beta_{6} Q_{6}+\beta_{7} Q_{7}+\beta_{8} Q_{8}+U_{i}
\end{aligned}
$$

where, $P_{i}$ is the probability of adoption and non-adoption of agricultural technologies; $P_{i}=1$ indicates adoption and $P_{i}$ $=0$ indicates non-adoption; $Z_{i}=$ Probability of adoption of agricultural technologies; $Q_{1}=$ Household size (no.); $Q_{2}=$ Educational level of household head (years of schooling); $Q_{3}=$ Age of household head (years); $Q_{4}=$ Farm size (ha); $Q_{5}=$ Farm income (Tk.); $Q_{6}=$ Non-farm income (Tk.); $Q_{7}$ $=$ Extension contact $\left(P_{i}=1\right.$ indicates having extension contact and $P_{i}=0$ indicates having no extension contact); $Q_{8}=$ Farming experience (years of farming); $\beta_{0}=$ Intercept; $\beta_{1}$ to $\beta_{8}=$ Regression coefficients of the dependent variables; and $U_{i}=$ Error term.

The marginal probabilities of the key determinants of adopting agricultural technologies by the farmers were 
estimated based on expressions derived from the marginal effect of the logit model which was estimated as:

$$
d Z / d Q=\beta_{i}\left\{P_{i}\left(1-P_{i}\right)\right\}
$$

Where:

$\beta_{i}=$ Estimated logit regression coefficient with respect to the $i^{\text {th }}$ factor

$P_{i}=$ Estimated probability of farmers' adoption status

\section{Results and Discussion}

\section{Production Practices in the Study Areas}

The production practices found in the study areas involved agricultural enterprises like crop, livestock, poultry and homestead enterprise. The most common farming practices were Crop-Livestock-Poultry (C-L-P), Crop-Poultry-Homestead enterprise (C-P-H) and CropLivestock-Homestead enterprise (C-L-H). Table 1 represents that majority of the farmers were engaged in $\mathrm{C}$ L-H farming system (44.6 and $44.3 \%$ farmers in Sylhet and Chittagong divisions, respectively) which was followed by C-L-P and C-P-H farming systems (36.7 and 31.7 and 18.7 and $24.0 \%$ farmers in Sylhet and Chittagong divisions, respectively). It was also experienced that C-L-P was mostly practiced by Khasia group (40.5\% farmers), C-P-H by Tanchang group (29.2\% farmers) and C-L-H by Garo group (49.3\% farmers) (Appendix 1). In addition, (Uddin et al., 2013) explored the indigenous knowledge of traditional farming system of Garo farmers on plain land, homestead and forestland with the objective of assessing its role in conserving the natural resources and stated that the Garo tribal group mainly adopted agroforestry and forestland management technique for their early income and livelihoods.

\section{Area under Agricultural Production}

It is evident from Table 2 that 84.8 and $82.7 \%$ of total cropped area of the farmers were under crop production (i.e., cereals crops, vegetables, spices and pulses) and 15.2 and $17.3 \%$ were under homestead enterprise (i.e., fruits and agroforestry) in Sylhet and Chittagong divisions, respectively. On an average, each household belonged 14 poultry birds (i.e., hen, pigeon and duck) and 7 small (i.e., goat and pig) and large (i.e., cow, ox and calf) livestock animals in Sylhet division and 15 poultry birds and 5 small and large livestock animals in Chittagong division.

\section{Profitability of Agricultural Enterprises}

The study calculated the profitability of agricultural enterprises (i.e., crop, livestock, poultry and homestead enterprise) under most common agricultural production practices.

Table 1: Production practices in the study areas

\begin{tabular}{|c|c|c|c|c|}
\hline \multirow[b]{3}{*}{ Farming practices } & \multicolumn{4}{|l|}{ Study areas } \\
\hline & \multicolumn{2}{|l|}{ Sylhet } & \multicolumn{2}{|l|}{ Chittagong } \\
\hline & No. of farmers & $\%$ of farmers & No. of farmers & $\%$ of farmers \\
\hline Crop-Livestock-Poultry (C-L-P) & 110 & 36.7 & 95 & 31.7 \\
\hline Crop-Poultry-Homestead enterprise (C-P-H) & 56 & 18.7 & 72 & 24.0 \\
\hline Crop-Livestock-Homestead enterprise (C-L-H) & 134 & 44.6 & 133 & 44.3 \\
\hline Total & 300 & 100.0 & 300 & 100.0 \\
\hline
\end{tabular}

Source: Field survey, 2018

Table 2: Area under agricultural enterprises

\begin{tabular}{|c|c|c|c|c|}
\hline \multicolumn{2}{|c|}{ Enterprises } & $\begin{array}{l}\text { Cultivated } \\
\text { area (ha) }\end{array}$ & $\begin{array}{l}\% \text { of total } \\
\text { cropped area }\end{array}$ & No./household \\
\hline \multicolumn{5}{|c|}{ Sylhet division (tribal groups: Garo, Khasia and Manipuri) } \\
\hline \multicolumn{2}{|c|}{ Crop (cereals crops, vegetables, spices and pulses) } & 0.39 & 84.8 & - \\
\hline \multicolumn{2}{|c|}{ Homestead enterprise (fruits and agroforestry) } & 0.07 & 15.2 & - \\
\hline \multicolumn{2}{|c|}{ Total cropped area } & 0.46 & 100.0 & - \\
\hline \multirow[t]{2}{*}{ Livestock } & Poultry (hen, pigeon and duck) & - & - & 14 \\
\hline & $\begin{array}{l}\text { Small and large animals } \\
\text { (cow, ox, calf, goat and pig) }\end{array}$ & - & - & 7 \\
\hline \multicolumn{5}{|c|}{ Chittagong division (tribal groups: Chakma, Marma and Tanchang) } \\
\hline \multicolumn{2}{|c|}{ Crop (cereals crops, vegetables, spices and pulses) } & 0.43 & 82.7 & - \\
\hline \multicolumn{2}{|c|}{ Homestead enterprise (fruits and agroforestry) } & 0.09 & 17.3 & - \\
\hline \multicolumn{2}{|c|}{ Total cropped area } & 0.52 & 100.0 & - \\
\hline \multirow[t]{2}{*}{ Livestock } & $\begin{array}{l}\text { Poultry (hen, pigeon and duck) } \\
\text { Small and large animals }\end{array}$ & - & - & 15 \\
\hline & (cow, ox, calf, goat and pig) & - & - & 5 \\
\hline
\end{tabular}

Source: Field survey, 2018 
Table 3: Crop profitability under common farming systems (Tk./ha)

\begin{tabular}{|c|c|c|c|c|c|c|c|}
\hline \multirow[b]{3}{*}{ Cost items } & & \multicolumn{6}{|c|}{ Study areas } \\
\hline & & \multicolumn{3}{|l|}{ Sylhet } & \multicolumn{3}{|c|}{ Chittagong } \\
\hline & & C-L-P & $\mathrm{C}-\mathrm{P}-\mathrm{H}$ & C-L-H & C-L-P & C-P-H & C-L-H \\
\hline \multicolumn{8}{|c|}{ Cost of crop production } \\
\hline \multirow[t]{6}{*}{ Variable costs } & Human labour & 13652.00 & 11235.00 & 18647.00 & 12485.00 & 11654.00 & 18220.00 \\
\hline & Power tiller & 3458.00 & 4940.00 & 4940.00 & 3625.00 & 4873.00 & 4871.00 \\
\hline & Seed/seedlings & 1258.00 & 1245.00 & 3520.00 & 1324.00 & 1325.00 & 3745.00 \\
\hline & Fertilizers & 6754.00 & 2159.00 & 4529.00 & 6248.00 & 2144.00 & 4610.00 \\
\hline & Insecticides & 2015.00 & 1986.00 & 2560.00 & 2314.00 & 1873.00 & 1424.00 \\
\hline & Irrigation & 9880.00 & 9880.00 & 9880.00 & 8867.00 & 9899.00 & 9755.00 \\
\hline \multicolumn{2}{|c|}{ i. Total variable cost } & 37017.00 & 31445.00 & 44076.00 & 34863.00 & 31768.00 & 42625.00 \\
\hline \multirow[t]{3}{*}{ Fixed costs } & Rental charge & 4586.00 & 4475.00 & 5120.00 & 4621.00 & 4593.00 & 5011.00 \\
\hline & Depreciation cost & 1247.00 & 1874.00 & 1582.00 & 1127.00 & 1821.00 & 1637.00 \\
\hline & Interest on operating capital & 2591.00 & 2439.00 & 2031.00 & 2440.00 & 2224.00 & 2984.00 \\
\hline \multicolumn{2}{|c|}{ ii. Total fixed cost } & 8424.00 & 8788.00 & 8733.00 & 8188.00 & 8638.00 & 9632.00 \\
\hline \multicolumn{2}{|c|}{ iii. Total cost (i + ii) } & 45441.00 & 40233.00 & 52809.00 & 43051.00 & 40406.00 & 52257.00 \\
\hline \multicolumn{8}{|c|}{ Return from crop production } \\
\hline \multicolumn{2}{|c|}{ iv. Gross return } & 49985.00 & 41038.00 & 55978.00 & 50049.00 & 42100.00 & 53907.00 \\
\hline \multicolumn{2}{|c|}{ v. Gross margin (iv-i) } & 12968.00 & 9593.00 & 11902.00 & 15186.00 & 10332.00 & 11282.00 \\
\hline \multicolumn{2}{|c|}{ vi. Net return (iv-iii) } & 4544.00 & 805.00 & 3169.00 & 6998.00 & 1694.00 & 1650.00 \\
\hline \multicolumn{2}{|c|}{ 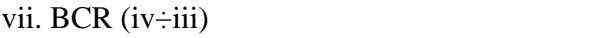 } & 1.10 & 1.02 & 1.06 & 1.16 & 1.04 & 1.03 \\
\hline
\end{tabular}

Source: Authors' estimation, 2018

\section{Profitability of Crop Production}

Profitability of crop production in Sylhet and Chittagong divisions under C-L-P, C-P-H and C-L-H farming systems are represented in Table 3. It is observed that total cost of crop production was Tk. 45441, Tk. 40233 and Tk. 52809; and Tk. 43051, Tk. 40406 and Tk. 52257 per hectare in C-L-P, C-P-H and C-L-H farming systems in Sylhet and Chittagong divisions, respectively. Net return from crop production was higher in C-L-P farming system (Tk. 4544 and Tk. 6998 per ha) compared to C-P-H (Tk. 805 and Tk. 1694 per ha) and C-L-H farming systems (Tk. 3169 and Tk. 1650 per ha) in Sylhet and Chittagong divisions, respectively. The BCR was higher in C-L-P farming system (i.e., 1.10 and 1.16) in both Sylhet and Chittagong divisions, respectively. The lower BCR motivated the tribal farmers to shift their concentration to livestock and poultry farming which can be seen in the upcoming sections.

\section{Profitability of Livestock Rearing}

Table 4 represents profitability of livestock rearing in Sylhet and Chittagong divisions under C-L-P and C-L-H farming systems. It is seen that total cost of livestock rearing per animal per year was Tk. 6096 and Tk. 5945 and Tk. 5741 and Tk. 5524 under C-L-P and C-L-H farming systems in Sylhet and Chittagong divisions, respectively. Net return from livestock rearing in C-L-P farming system was much higher than in C-L-H farming system (Tk. 6828 and Tk. 6520 and Tk. 5626 and Tk. 5662 per animal per year in C-L-P and C-L-H farming systems in Sylhet and Chittagong divisions, respectively). The BCR was found as 2.12 and 2.10 and 1.98 and 2.02 under C-L-P and C-L-H farming systems in Sylhet and Chittagong divisions, respectively indicating C-L-P farming system more profitable compared to C-L-H farming system.

\section{Profitability of Poultry Rearing}

Profitability of poultry rearing under C-L-P and C-P$\mathrm{H}$ farming systems in Sylhet and Chittagong divisions is depicted in Table 5. It is found that net return from poultry rearing in C-L-P farming system was comparatively higher than C-P-H farming system (Tk. 277 and Tk. 268 and Tk. 159 and Tk. 159 per bird per year in Sylhet and Chittagong divisions) where the total cost was Tk. 243 and Tk. 247 and Tk. 249 and Tk. 253 per bird per year in Sylhet and Chittagong divisions, respectively. The BCR of poultry rearing was higher in C-L-P farming system (i.e., 2.13 and 2.09) in respect of C-P-H farming system (i.e., 2.03 and 1.63) in Sylhet and Chittagong divisions, respectively.

\section{Profitability of Homestead Enterprise}

Table 6 shows profitability of homestead enterprise in C-L-H and C-P-H farming systems in Sylhet and Chittagong divisions. It is apparent that total cost of homestead enterprise was Tk. 51640 and Tk. 49706 and Tk. 47874 and Tk. 48960 per ha under C-L-H and C-P-H farming systems in Sylhet and Chittagong divisions, respectively. Net return under C-L-H farming system (i.e., Tk. 4131 and Tk. 7013) was relatively higher with regard to C-P-H farming system (i.e., Tk. 1915 and Tk. 4786) in Sylhet and Chittagong divisions, respectively. The BCR of homestead enterprise under C-L-H and C-P-H farming systems was 1.08 and 1.14 and 1.04 and 1.10 in Sylhet and Chittagong divisions, respectively. 
Table 4: Profitability of livestock rearing under most common farming systems (Tk./animal/year)

\begin{tabular}{|c|c|c|c|c|c|}
\hline \multirow{3}{*}{ Cost items } & & \multicolumn{4}{|c|}{ Study areas } \\
\hline & & \multicolumn{2}{|l|}{ Sylhet } & \multicolumn{2}{|c|}{ Chittagong } \\
\hline & & C-L-P & C-L-H & C-L-P & $\mathrm{C}-\mathrm{L}-\mathrm{H}$ \\
\hline \multicolumn{6}{|c|}{ Cost of livestock rearing } \\
\hline \multirow[t]{5}{*}{ Variable costs } & Human labour & 1250.00 & 1158.00 & 1294.00 & 1029.00 \\
\hline & Feed & 365.00 & 401.00 & 376.00 & 482.00 \\
\hline & Artificial insemination & 256.00 & 269.00 & 215.00 & 271.00 \\
\hline & Vitamin and medicine & 495.00 & 365.00 & 509.00 & 304.00 \\
\hline & Maintenance & 1200.00 & 1069.00 & 1149.00 & 1000.00 \\
\hline \multicolumn{2}{|c|}{ i. Total variable cost } & 3566.00 & 3262.00 & 3543.00 & 3086.00 \\
\hline \multirow[t]{4}{*}{ Fixed costs } & Rental charge & 1254.00 & 1248.00 & 1173.00 & 1195.00 \\
\hline & Housing cost & 569.00 & 589.00 & 519.00 & 627.00 \\
\hline & Depreciation cost & 457.00 & 414.00 & 462.00 & 400.00 \\
\hline & Interest on operating capital & 250.00 & 228.00 & 248.00 & 216.00 \\
\hline \multicolumn{2}{|c|}{$\begin{array}{l}\text { ii. Total fixed cost } \\
\text { iii. Total cost (i+ii) }\end{array}$} & 2530.00 & 2479.00 & 2402.00 & 2438.00 \\
\hline iii. Total cost ( & & 6096.00 & 5741.00 & 5945.00 & 5524.00 \\
\hline \multicolumn{6}{|c|}{ Return from livestock rearing } \\
\hline \multicolumn{2}{|l|}{ iv. Gross return } & 12924.00 & 11367.00 & 12465.00 & 11186.00 \\
\hline \multicolumn{2}{|c|}{ v. Gross margin (iv-i) } & 9358.00 & 8105.00 & 8922.00 & 8100.00 \\
\hline \multicolumn{2}{|c|}{ vi. Net return (iv-iii) } & 6828.00 & 5626.00 & 6520.00 & 5662.00 \\
\hline \multicolumn{2}{|c|}{ vii. BCR (iv-iii) } & 2.12 & 1.98 & 2.10 & 2.02 \\
\hline
\end{tabular}

Source: Authors' estimation, 2018

Table 5: Profitability of poultry rearing under most common farming systems (Tk./bird/year)

\begin{tabular}{|c|c|c|c|c|c|}
\hline \multirow[b]{3}{*}{ Cost items } & & \multicolumn{4}{|c|}{ Study areas } \\
\hline & & \multicolumn{2}{|l|}{ Sylhet } & \multicolumn{2}{|c|}{ Chittagong } \\
\hline & & C-L-P & C-P-H & C-L-P & C-P-H \\
\hline \multicolumn{6}{|c|}{ Cost of poultry rearing } \\
\hline \multirow[t]{4}{*}{ Variable costs } & Human labour & 42.00 & 40.00 & 45.00 & 42.00 \\
\hline & Feed & 110.00 & 122.00 & 105.00 & 125.00 \\
\hline & Vitamin and medicine & 30.00 & 28.00 & 35.00 & 30.00 \\
\hline & Maintenance & 10.00 & 11.00 & 12.00 & 10.00 \\
\hline \multicolumn{2}{|c|}{ i. Total variable cost } & 192.00 & 201.00 & 197.00 & 207.00 \\
\hline \multirow[t]{4}{*}{ Fixed costs } & Rental charge & 8.00 & 8.00 & 9.00 & 8.00 \\
\hline & Housing cost & 12.00 & 11.00 & 10.00 & 12.00 \\
\hline & Depreciation cost & 15.00 & 12.00 & 17.00 & 12.00 \\
\hline & Interest on operating capital & 16.00 & 17.00 & 14.00 & 14.00 \\
\hline \multicolumn{2}{|c|}{ ii. Total fixed cost } & 51.00 & 48.00 & 50.00 & 46.00 \\
\hline \multicolumn{2}{|c|}{ iii. Total cost (i+ii) } & 243.00 & 249.00 & 247.00 & 253.00 \\
\hline \multicolumn{6}{|c|}{ Return from poultry rearing } \\
\hline \multicolumn{2}{|l|}{ iv. Gross return } & 520.00 & 408.00 & 515.00 & 412.00 \\
\hline \multicolumn{2}{|c|}{ v. Gross margin (iv-i) } & 328.00 & 207.00 & 318.00 & 205.00 \\
\hline \multicolumn{2}{|c|}{ vi. Net return (iv-iii) } & 277.00 & 159.00 & 268.00 & 159.00 \\
\hline \multicolumn{2}{|l|}{ vii. BCR (iv־iii) } & 2.13 & 2.03 & 2.09 & 1.63 \\
\hline
\end{tabular}

Source: Authors' estimation, 2018

Average profitability scenario of the farmers in Sylhet and Chittagong divisions represented that among all the agricultural enterprises, on an average, poultry rearing was the highest profitable business in Sylhet division (with BCR 2.08) and livestock rearing was the highest profitable business in Chittagong division (with BCR 2.06) for the farmers. As crop production and homestead farming were not as profitable as livestock and poultry rearing, farmers gradually shifted their concentration to livestock and poultry production. In case of crop production, the BCR was highest as 1.18 for Chakma and Tanchang groups in C-L-P, 1.04 for Chakma and Marma groups in C-P-H and 1.06 for Manipuri group in C-L-H. In terms of livestock rearing, the BCR was highest as 2.14 for Khasia group in C-L-P and 2.04 for Tanchang group in C-L-H. In stare of poultry rearing, the BCR was highest as 2.14 for Manipuri group in C-L-P and 2.06 for Khasia group in C-P-H. Lastly, in case of homestead enterprise, the BCR was highest as 1.14 for Marma and Tanchang groups in C-L-H and 1.13 for Chakma group in C-P-H 
(Appendix 2). On the contrary, (Raghav and Srivastava, 2015) found crop enterprises more profitable than livestock and orchard enterprises in Uttarakhand, India.

\section{Measurement of Crop Productivity}

Using Enyedi's crop productivity index, the average crop productivity in Sylhet and Chittagong divisions was estimated in comparison with the crop production in the entire region which is represented by Table 7 . It is seen that per hectare crop production of the farmers was 14.15 and 14.58 ton in Sylhet and Chittagong divisions, respectively. Total cultivated area and crop production in the entire region of Sylhet and Chittagong divisions were found at 4856 and 5620 ha and 103482.54 and 105127.92 ton per ha, respectively. The estimated crop productivity index value was 144.3 and 149.9 percent in Sylhet and Chittagong divisions which indicates that crop productivity was of moderately high range in the study areas. But Krishnani et al. (2017) argued that the agricultural production and productivity of principal crops were low and fluctuating in Nandurbar District of India as compared with state as well regional level.

\section{Net Change in Inventory of Livestock}

Net change in inventory of livestock was calculated by deducting the sum of opening stock and bought from the sum of closing stock, consumed/gifted, sold and died. From Table 8 it is seen that inventory change in case of goat was the highest among all livestock enterprises (Tk. 4850 and Tk. 5700 in Sylhet and Chittagong divisions, respectively). Average net change in inventory in Sylhet and Chittagong divisions was estimated at Tk. 16615 and Tk. 19125, respectively. In comparison, net change in inventory was the highest in case of Khasia group in Sylhet division (Tk. 17169) and in case of Marma group in Chittagong division which was Tk. 19383 (Appendix 3). The findings are quite similar with Ahmed 2015 where the author found that net change in inventory was Tk. 12223.3 on an average in char areas of northern Bangladesh.

Table 6: Profitability of homestead enterprise (Tk./ha)

\begin{tabular}{|c|c|c|c|c|c|}
\hline \multirow[b]{3}{*}{ Cost items } & & \multicolumn{4}{|c|}{ Study areas } \\
\hline & & \multicolumn{2}{|l|}{ Sylhet } & \multicolumn{2}{|c|}{ Chittagong } \\
\hline & & C-L-H & C-P-H & C-L-H & C-P-H \\
\hline \multicolumn{6}{|c|}{ Cost of homestead enterprise } \\
\hline \multirow[t]{6}{*}{ Variable costs } & Human labour & 14578.00 & 12457.00 & 15672.00 & 13525.00 \\
\hline & Seed/seedlings & 4852.00 & 4820.00 & 4732.00 & 4750.00 \\
\hline & Fertilizers & 6485.00 & 5861.00 & 6490.00 & 5900.00 \\
\hline & Insecticides & 1254.00 & 1342.00 & 1359.00 & 1437.00 \\
\hline & Irrigation & 4940.00 & 4940.00 & 1744.00 & 4830.00 \\
\hline & Maintenance & 8475.00 & 7425.00 & 8500.00 & 7500.00 \\
\hline i. Total variable & & 40584.00 & 36845.00 & 38497.00 & 37942.00 \\
\hline \multirow{2}{*}{$\begin{array}{l}\text { 1. I otal variabl } \\
\text { Fixed costs }\end{array}$} & Lease value & 8215.00 & 8450.00 & 8514.00 & 8362.00 \\
\hline & Interest on operating capital & 2841.00 & 2579.00 & 2695.00 & 2656.00 \\
\hline & 11056.00 & 11029.00 & 11209.00 & 11018.00 \\
\hline \multicolumn{2}{|c|}{ iii. Total cost $(\mathrm{i}+\mathrm{ii})$} & 51640.00 & 47874.00 & 49706.00 & 48960.00 \\
\hline \multicolumn{6}{|c|}{ Return from homestead enterprise } \\
\hline \multicolumn{2}{|c|}{ iv. Gross return } & 55771.00 & 49789.00 & 56719.00 & 53746.00 \\
\hline \multicolumn{2}{|c|}{ v. Gross margin (iv-i) } & 15187.00 & 12944.00 & 18222.00 & 15804.00 \\
\hline \multicolumn{2}{|c|}{ vi. Net return (iv-iii) } & 4131.00 & 1915.00 & 7013.00 & 4786.00 \\
\hline \multicolumn{2}{|c|}{ vii. BCR (iv $\div$ iii) } & 1.08 & 1.04 & 1.14 & 1.10 \\
\hline
\end{tabular}

Source: Authors' estimation, 2018

Table 7: Enyedi's crop productivity index (in average)

\begin{tabular}{lcc} 
& Study areas & \\
& $-\mathrm{s}$ Chittagong (tribal groups: \\
Particulars & Sylhet (tribal groups: & Chakma, Marma and Tanchang) \\
\hline Production (ton/ha) & 14.15 & 14.58 \\
Total production in the entire region (ton) & 103482.54 & 105127.92 \\
Cultivated area (ha) & 0.46 & 0.52 \\
Total cultivated area in the entire region (ha) & 4856.00 & 5620.00 \\
Crop productivity (\%) & 144.30 & 149.90 \\
\hline
\end{tabular}

Source: Authors' estimation, 2018

Note: Information on total cultivated area and production in the entire region were collected from (BBS, 2015) 


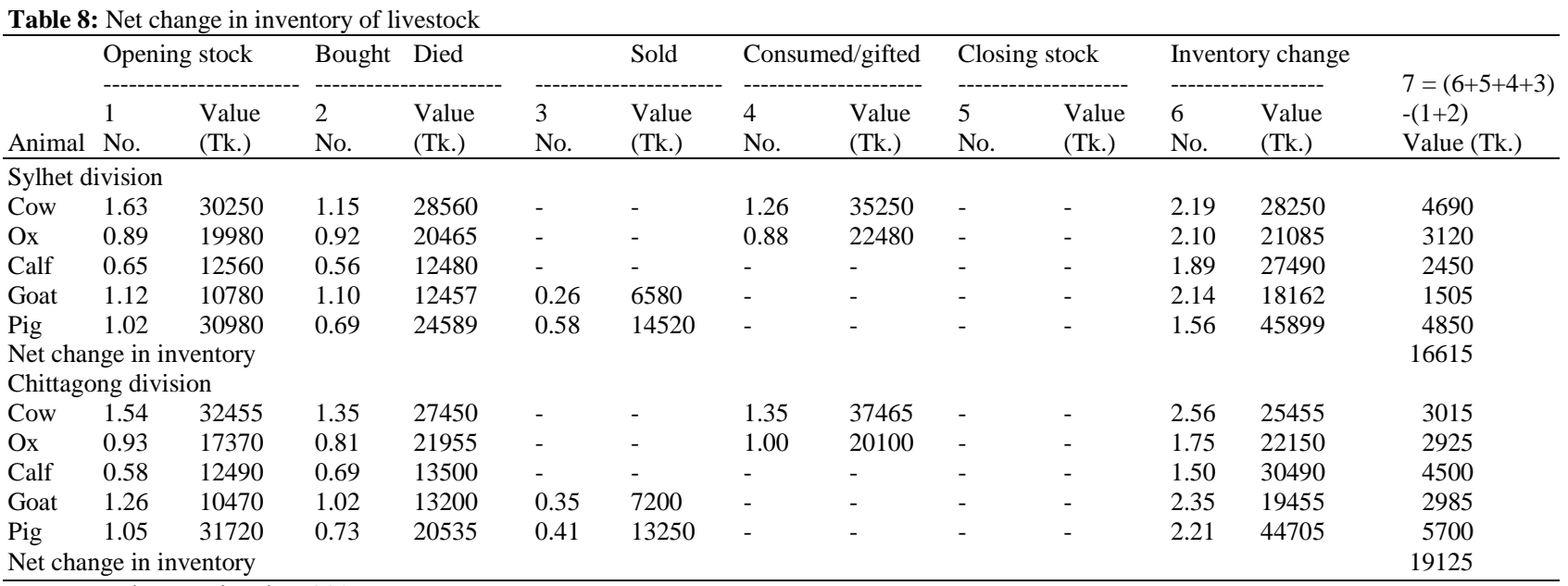

Source: Authors' estimation, 2017-18

Table 9: Extent of change in production practices after using agricultural technologies

\begin{tabular}{|c|c|c|c|c|c|c|}
\hline \multirow[b]{3}{*}{ Items } & \multicolumn{6}{|c|}{ Study areas } \\
\hline & \multicolumn{3}{|c|}{$\begin{array}{l}\text { Sylhet } \\
\text { (tribal groups: Garo, Khasia and Manipuri) }\end{array}$} & \multicolumn{3}{|c|}{$\begin{array}{l}\text { Chittagong } \\
\text { (tribal groups: Chakma, Marma and Tanchang) }\end{array}$} \\
\hline & Increased & Decreased & Constant & Increased & Decreased & Constant \\
\hline Labour use & 8.5 & 59.2 & 32.3 & 9.2 & 54.0 & 36.8 \\
\hline Expenditure in production & 41.2 & 18.0 & 40.8 & 43.1 & 19.6 & 37.3 \\
\hline Complexity in practice & 49.6 & 12.0 & 38.4 & 47.5 & 15.0 & 37.5 \\
\hline Time consumption & 16.2 & 58.4 & 25.4 & 19.6 & 57.5 & 22.9 \\
\hline Need of intensive care & 40.4 & 22.8 & 36.8 & 37.5 & 26.0 & 36.5 \\
\hline Growth of crops & 54.4 & 16.4 & 29.2 & 59.0 & 18.0 & 23.0 \\
\hline Productivity of enterprises & 54.0 & 19.2 & 26.8 & 55.6 & 17.0 & 27.4 \\
\hline Tillage operation & 28.6 & 39.7 & 31.7 & 21.9 & 40.2 & 37.9 \\
\hline Use of irrigation water & 54.5 & 16.0 & 29.5 & 51.7 & 15.8 & 32.5 \\
\hline Land under cultivation & 41.0 & 24.5 & 34.5 & 43.8 & 20.9 & 35.3 \\
\hline Pest management & 25.5 & 15.0 & 59.5 & 27.6 & 18.5 & 53.9 \\
\hline Grain quality & 36.4 & 24.8 & 38.8 & 32.8 & 25.0 & 42.2 \\
\hline
\end{tabular}

Source: Field survey, 2017-18

\section{Impact of using Agricultural Technologies on Production Practices}

It is found from the study that the tribal farmers in the research areas practice agricultural technologies like betel leaf and betel nut production, ell fish production (Monopterus Cuchia, Eng. Name-Cuchia), agroferestry plantation, coffee tree cultivation, Jhum Cultivation, medicinal plants cultivation and rice cultivation (local). To appraise the impact of using these agricultural technologies on production practices in Sylhet and Chittagong divisions, the researchers made discussion with the farmers about their perception on the change of their agricultural practices before and after using the technologies (Table 9).

It is seen that most of the farmers experienced increase in weed control, use of irrigation water and growth and productivity of crops (59.6, 54.5, 54.4 and 54.0 and 55.0,
51.7, 59.0 and 55.6\% farmers in Sylhet and Chittagong divisions, respectively). Some of them stated about decreased labour use, time consumption and tillage operation (59.2, 58.4 and 39.7 and 54.0, 57.5 and $40.2 \%$ farmers in Sylhet and Chittagong divisions, respectively). On the other hand, 59.5, 40.8 and 38.8 and 53.9, 37.3 and 42.2\% farmers in Sylhet and Chittagong divisions opined about constant aspects of pest management, expenditure in production and grain quality, respectively. Overall, 39.2, 26.6 and 34.2 and 38.8, 26.5 and 34.7\% farmers in Sylhet and Chittagong divisions assured about increased, decreased and constant state of production practices, respectively. By analyzing the impacts of new technologies like agricultural biotechnology and automatic milking in Belgium, (Demont et al., 2001) concluded that both technologies offered likely financial aids to farmers through increasing yields and reducing input use and cost. 
Table 10: Estimates of logistic regression of determinants adopting agricultural technologies

\begin{tabular}{|c|c|c|c|c|c|c|}
\hline Variables & Coefficient $(\beta)$ & Standard error & $\mathrm{Z}$ & $\mathrm{P}>|\mathrm{z}|$ & \multicolumn{2}{|c|}{$95 \%$ confidence interval } \\
\hline Constant & 2.178 & 1.588 & 1.37 & 0.170 & -0.936 & 5.291 \\
\hline Household size $\left(\mathrm{Q}_{1}\right)$ & 0.005 & 0.002 & 2.70 & 0.379 & -0.009 & -0.001 \\
\hline Educational level of household head $\left(\mathrm{Q}_{2}\right)$ & $1.131 * *$ & 0.435 & 2.60 & 0.031 & -1.984 & -0.278 \\
\hline Age of household head $\left(\mathrm{Q}_{3}\right)$ & -1.137 & 0.436 & -1.01 & 0.209 & 0.023 & 1.992 \\
\hline Farm size $\left(Q_{4}\right)$ & $1.127 *$ & 0.435 & 2.59 & 0.083 & 0.273 & 1.980 \\
\hline Farm income $\left(Q_{5}\right)$ & $1.129 *$ & 0.435 & 2.59 & 0.070 & 0.275 & 1.982 \\
\hline Non-farm income $\left(\mathrm{Q}_{6}\right)$ & -0.022 & 0.021 & -1.06 & 0.291 & -0.062 & 0.019 \\
\hline Extension contact $\left(\mathrm{Q}_{7}\right)$ & $0.087 * * *$ & 0.100 & 0.87 & 0.004 & -0.109 & 0.284 \\
\hline Farming experience $\left(\mathrm{Q}_{8}\right)$ & $0.023 *$ & 0.072 & 0.32 & 0.086 & -0.119 & 0.164 \\
\hline
\end{tabular}

Source: Authors' estimation, 2018

Note: $* * * * *$ and $*$ indicate significant at 1,5 and $10 \%$ probability level, respectively

Table 11: Estimates of marginal effect of determinants adopting agricultural technologies

\begin{tabular}{|c|c|c|c|c|c|c|c|}
\hline Variables & $\mathrm{dZ} / \mathrm{dQ}$ & Standard error & $\mathrm{z}$ & $\mathrm{P}>|\mathrm{z}|$ & \multicolumn{2}{|c|}{$95 \%$ confidence interval } & Q \\
\hline Household size $\left(\mathrm{Q}_{1}\right)$ & 0.001 & 0.001 & 2.69 & 0.107 & -0.002 & -0.000 & 5.000 \\
\hline Educational level of household head $\left(\mathrm{Q}_{2}\right)$ & $0.281 * *$ & 0.108 & 2.61 & 0.039 & -0.492 & -0.070 & 3.000 \\
\hline Age of household head ( $\left.Q_{3}\right)$ & -0.283 & 0.108 & -2.62 & 0.239 & 0.071 & 0.494 & 37.000 \\
\hline Farm size $\left(Q_{4}\right)$ & $0.280 *$ & 0.108 & 2.60 & 0.092 & 0.069 & 0.491 & 5.043 \\
\hline Farm income $\left(Q_{5}\right)$ & $0.280 *$ & 0.108 & 2.60 & 0.061 & 0.069 & 0.492 & 51196.000 \\
\hline Non-farm income $\left(Q_{6}\right)$ & -0.005 & 0.005 & -1.06 & 0.291 & -0.015 & 0.005 & 38580.000 \\
\hline Extension contact $\left(\mathrm{Q}_{7}\right)$ & $0.023 * * *$ & 0.025 & 0.87 & 0.005 & -0.027 & 0.070 & 0.804 \\
\hline Farming experience $\left(\mathrm{Q}_{8}\right)$ & $0.006^{*}$ & 0.018 & 0.32 & 0.053 & -0.029 & 0.041 & 3.000 \\
\hline
\end{tabular}

Source: Author's estimation, 2015-16

Note: $* * *, * *$ and $*$ indicate significant at 1,5 and $10 \%$ probability level, respectively

Factors Determining Farmers' Adoption of Agricultural Technologies

Five (05) out of eight (08) explanatory variables included in the logistic regression model were found significant in explaining the variation in adopting agricultural technologies by the farmers. These variables were educational level of household head, farm size, farm income, extension contact and farming experience of the farmers in the research areas (Table 10 and 11).

Therefore the estimated equation was as follows:

$$
\begin{aligned}
& Z_{i}=2.178+0.005 Q_{1}+1.131 Q_{2}-1.137 Q_{3} \\
& +1.127 Q_{4}+1.129 Q_{5}-0.022 Q_{6}+0.087 Q_{7}+0.023 Q_{8}
\end{aligned}
$$

The results of marginal effect show that if educational level of household head, farm size, farm income and farming experience of the farmers are increased by 1 unit, the probability of adopting agricultural technologies will be increased by $0.281,0.280,0.280$ and 0.006 times, respectively. Farmers could gain better knowledge about agricultural technologies which could insist them to adopt the modern technologies. Furthermore, farmers whose farm size was large, tended to apply new agricultural technologies in a remarkable amount of cropland while practicing traditional agricultural technologies in others. In addition, farmers allowed adopting new agricultural technologies anticipating extra monetary income from agricultural production. Also, farmers having existing knowledge and training on new agricultural technologies were aware about its positives and negatives which incited them for adopting the technologies. The probability of adopting agricultural technologies for those farmers who have extension contact is 0.023 times higher compared to those farmers who do not have extension contact. The reason was that farmers got influenced and motivated by the extension agents to adopt modern agricultural technologies.

The findings are quite similar to some previous studies. Dhraief et al. (2018) found that farm education, size of cattle flocks and off-farm income had statistically significant and positive influence on technology adoption, while age and farm experience had significant and negative effects on adoption decision of innovative technologies in Tunisia. Kinyangi (2014) found capital and credit facilities, training, agricultural extension services, market availability, farmers' educational levels, gender and farmers' age having positive and significant influence on the adoption of technology in Kenya. Farid et al. (2015) revealed that communication score, total cultivable land and socioeconomic score had significant positive relationship and total land area affected due to drought had significant negative relationship with adoption of improved farm practices by the Bangladeshi farmers.

\section{Conclusion}

The study came to a conclusion that sustainable agricultural development is needed to help tribal agriculture to be modernized. The most common farming practices were crop-livestock-poultry (C-L-P), crop-poultryhomestead enterprise (C-P-H) and crop-livestockhomestead enterprise (C-L-H). Almost all of the most 
common farming practices like C-L-P, C-P-H and C-L-H were more or less profitable. Crop productivity of the farmers using agricultural technologies was moderately high in response to the crop production in the entire region. Net change in inventory of livestock was satisfactory also. The study exposed that majority of the farmers avowed about enhanced state of production practices using agricultural technologies like betel leaf and betel nut production, ell fish production (Monopterus Cuchia, Eng. Name-Cuchia), agroferestry plantation, coffee tree cultivation, Jhum Cultivation, medicinal plants cultivation and rice cultivation (local). Educational level of household head, farm size, farm income, extension contact and farming experience had significant influence on adoption of agricultural technologies by the farmers. Considering the findings of the study, some essential policy recommendations have been arisen which are: Training, motivation and extension services of government should be properly implemented to raise the awareness about modern agricultural technologies and its importance on agricultural production among the tribal groups. Also, initiative for scientific and technical training programmes should be arranged by different government and non-government organizations to enrich the knowledge of the farmers on agricultural technology use.

\section{Acknowledgement}

The study is funded by the research grant of USAID Trust Fund and GoB through Ministry of Agriculture. Cordial thanks are extended to the World Bank for arranging the grand fund and supervising the CRGs by BARC. It is worthwhile to mention the cooperation and quick responses of PIU-BARC, NATP 2, in respect of field implementation of the sub-project in multiple sites.

\section{Author's Contributions}

Jasim Uddin Ahmed: Designed and coordinated the study, checked the analyzed data, supervised the draft manuscript and approved the final manuscript.

Md. Abul Kashem: Contributed in data interpretation and reviewed the draft manuscript.

Tabia Binte Shan: Collected and analyzed data, and prepared the draft manuscript.

Prashanta Das: Collected and analyzed data, and prepared the draft manuscript.

Md. Mosharraf Uddin Molla: Contributed in data interpretation and reviewed the draft manuscript.

\section{Ethics}

This article is original and contains unpublished material. The corresponding author confirms that all of the other authors have read and approved the manuscript and no ethical issues involved.

\section{References}

Ahmmed, F. (2012). Challenges of aging and coping mechanisms among the Khasi and Garo tribal groups: an ethnographic observation. Journal of International Social Issues, 23-38. https://doi.org/10.5958/j.2231-4547.1.1.007

Barman, D. C., \& Neo, M. S. (2014). Human Rights Report 2013: On Indigenous Peoples in Bangladesh. Kapaeeng Foundation, Dhaka, Bangladesh. https://www.amazon.com/Human-Rights-Report2013-Indigenous/dp/9843363671

BBS. (2015). Statistical Yearbook of Bangladesh, Bangladesh Bureau of Statistics, Statistics Division, Ministry of Planning, Government of the People's Republic of Bangladesh, Dhaka. http://203.112.218.65:8008/WebTestApplication/userfi les/Image/SubjectMatterDataIndex/YearBook15.pdf

Begum, S. (2015). Impact of agricultural modernization on sustainable livelihood among the tribal. International Journal of Research in Humanities, Arts and Literature, 3(5), 55-66. file:///c:/users/it\%20department/downloads/2-111431148763-6.humimpact $\% 20$ of\%20agricultural\%20modernization $\% 2$ 0on\%20sustainable\%20-sabina\%20begum.pdf

Datta, J., Gangadharappa, N. R., Biradar, G. S., \& Kendra, G. K. V. (2014). Livelihood status of tribal people practicing shifting (jhum) cultivation in Tripura state of North-East India. Tropical Agricultural Research, 25(3), 316-326. https://doi.org/10.4038/tar.v25i3.8042

Demont, M., Mathijs, E., \& Tollens, E. (2001). Impact of new technologies on agricultural production systems: The cases of agricultural biotechnology and automatic milking. In: Bouquiaux, J. M., Lauwers, L., \& Viaene, J. (Eds.), New Technologies and Sustaintability, (pp. 11-38), Brussels: CLE-CEA. https://www.biw.kuleuven.be/aee/clo/wp/Demont20 01e.pdf

Dhraief, M. Z., Bedhiaf-Romdhania, S., Dhehibib, B., Oueslati-Zlaouia, M., Jebali, O., \& Ben Youssef, S. (2018). Factors affecting the adoption of innovative technologies by livestock farmers in arid area of Tunisia. FARA Res. Rep, 3(5), 22. https://doi.org/10.30682/nm1904a

Dillon, J. L., \& Hardaker, J. B. (1993). Farm Management Research for Small Farmer Development, FAO, Rome, ISBN-10: 9251033056.

Farid, K. S., Tanny, N. Z., \& Sarma, P. K. (2015). Factors affecting adoption of improved farm practices by the farmers of Northern Bangladesh. Journal of the Bangladesh Agricultural University, 13(452-2016-35870), 291-298. https://doi.org/10.3329/jbau.v13i2.28801

Gujarati, D. N. (2003). Basic Econometrics 4th edition McGraw Hill: New York. 
Kabir, G. (2002). Participation of male Garo youth in selected income earning agricultural activities in haughty Upazila Under Mymensingh District. MS (Ag. Ext. Ed.) (Doctoral dissertation, Thesis, Department of Agricultural Extension Education, Bangladesh Agri-cultural University, Mymensingh).

Kassie, G. W., Kim, S., \& Fellizar, F. P. (2017). Determinant factors of livelihood diversification: Evidence from Ethiopia. Cogent Social Sciences, 3(1), 1369490. https://doi.org/10.1080/23311886.2017.1369490

Kinyangi, A. A. (2014). Factors influencing the adoption of agricultural technology among smallholder farmers in Kakamega north sub-county, Kenya (Doctoral dissertation, University of Nairobi). http://erepository.uonbi.ac.ke/handle/11295/76086

Krishnani, K. K., Kurade, N. P., Patel, D. P., Kamble, A. L., Meena, R. L., Kumar, N., Nirmale, A. V., Minhas, P. S., \& Singh, N. P. (2017). A Step towards Improving Livelihood of Tribal Farmers through Integrated Farming. Technical Bulletin No.10, ICAR-National Institute of Abiotic Stress Management, Pune, Maharashtra, India. http://www.niam.res.in/sites/default/files/pdfs/TechBulletine-10.pdf

Melesse, B. (2018). A review on factors affecting adoption of agricultural new technologies in Ethiopia. Journal of Agricultural Science and Food Research, 9(3), 1-4. https://www.longdom.org/openaccess/a-review-on-factors-affecting-adoption-ofagricultural-new-technologiesin-ethiopia.pdf
MoA. (1996). New Agricultural Extension Policy (NAEP). Ministry of Agriculture, Government of the People's Republic of Bangladesh. https://dae.portal.gov.bd/sites/default/files/files/dae. portal.gov.bd/page/dd7d2be1_aeef_452f_9774_8c23 462ab73a/NAEP.pdf

Nath, T. K., Makoto, I., Islam, M. J., \& Kabir, M. A. (2003). The Khasia tribe of northeastern Bangladesh: their socio-economic status, hill farming practices and impacts on forest conservation. Forests, trees and livelihoods, 13(4), 297-311. https://doi.org/10.1080/14728028.2003.9752467

Ogale, S., \& Nagarale, V. (2014). Agricultural productivity of the Baramati Tahsil, Pune district (Maharashtra). IOSR Journal of Agriculture and Veterinary $\quad$ Science, $\quad 7(5), \quad$ 25-30. https://doi.org/10.9790/2380-07522530

Raghav, S., \& Srivastava, S. K. (2015). Profitability of farming systems on tribal farms in Udham Singh Nagar District of Uttarakhand, India. Agricultural Science Digest, 35(3). https://doi.org/10.5958/09760547.2015.00050.6

Uddin, M. S., Ahmed, R., Khan, M. F. K., Khan, M. A. S. A., \& Rahman, M. S. (2013). Traditional farming system of Garo tribe in Netrokona district of Bangladesh. https://pas.cseas.kyotou.ac.jp/activity/HP_SPIRITS/Brahmaputra/data/JAE _ALL/ASFBpdf/1.AFSB1(1)pdf/9.\%20Shoibur.pdf

Appendix 1: Tribal groups' comparison on production practices ( $\%$ of farmers)

\begin{tabular}{|c|c|c|c|c|c|c|}
\hline \multirow[b]{3}{*}{ Farming practices } & \multicolumn{6}{|c|}{ Study areas } \\
\hline & \multicolumn{3}{|l|}{ Sylhet } & \multicolumn{3}{|c|}{ Chittagong } \\
\hline & Garo & Khasia & Manipuri & Chakma & Marma & Tanchang \\
\hline Crop-Livestock-Poultry (C-L-P) & 32.8 & 40.5 & 36.0 & 29.7 & 32.4 & 31.0 \\
\hline Crop-Poultry-Homestead Enterprise (C-P-H) & 17.9 & 16.7 & 19.5 & 26.5 & 25.7 & 29.2 \\
\hline Crop-Livestock-Homestead Enterprise (C-L-H) & 49.3 & 42.8 & 44.5 & 43.8 & 41.9 & 39.8 \\
\hline Total & 100.0 & 100.0 & 100.0 & 100.0 & 100.0 & 100.0 \\
\hline
\end{tabular}

Source: Field survey, 2018

Appendix 2: Tribal groups' comparison on BCR of agricultural enterprises

\begin{tabular}{|c|c|c|c|c|c|c|c|}
\hline \multirow{3}{*}{$\begin{array}{l}\text { Agricultural } \\
\text { enterprises }\end{array}$} & \multirow{3}{*}{$\begin{array}{l}\text { Farming } \\
\text { systems }\end{array}$} & \multicolumn{6}{|c|}{ Study areas } \\
\hline & & \multicolumn{3}{|l|}{ Sylhet } & \multicolumn{3}{|c|}{ Chittagong } \\
\hline & & Garo & Khasia & Manipuri & Chakma & Marma & Tanchang \\
\hline \multirow[t]{3}{*}{ Crop production } & C-L-P & 1.08 & 1.10 & 1.11 & 1.18 & 1.17 & 1.18 \\
\hline & C-P-H & 1.02 & 1.02 & 1.00 & 1.04 & 1.04 & 1.03 \\
\hline & C-L-H & 1.03 & 1.03 & 1.06 & 1.03 & 1.05 & 1.04 \\
\hline \multirow{2}{*}{ Livestock rearing } & C-L-P & 2.09 & 2.14 & 2.10 & 2.10 & 2.10 & 2.09 \\
\hline & C-L-H & 1.94 & 2.00 & 1.98 & 2.01 & 1.99 & 2.04 \\
\hline \multirow[t]{2}{*}{ Poultry rearing } & C-L-P & 2.13 & 2.12 & 2.14 & 2.09 & 2.05 & 2.10 \\
\hline & C-P-H & 2.04 & 2.06 & 1.99 & 1.65 & 1.64 & 1.69 \\
\hline \multirow[t]{2}{*}{ Homestead enterprise } & C-L-H & 1.13 & 1.08 & 1.11 & 1.12 & 1.14 & 1.14 \\
\hline & C-P-H & 1.01 & 1.06 & 1.04 & 1.13 & 1.09 & 1.10 \\
\hline
\end{tabular}

Source: Authors' estimation, 2018 
Jasim Uddin Ahmed et al. / Journal of Social Sciences 2021, Volume 17: 106.117 DOI: $10.3844 /$ jssp.2021.106.117

Appendix 3: Tribal groups' comparison on net change in inventory of livestock Study areas

\begin{tabular}{|c|c|c|c|c|c|c|}
\hline \multirow{3}{*}{$\begin{array}{l}\text { Inventory change } \\
\text { for animals }\end{array}$} & \multirow{2}{*}{\multicolumn{3}{|c|}{ Sylhet }} & \multirow{2}{*}{\multicolumn{3}{|c|}{ Chittagong }} \\
\hline & & & & & & \\
\hline & Garo & Khasia & Manipuri & Chakma & Marma & Tanchang \\
\hline Cow & 4583 & 4890 & 4761 & 2964 & 3075 & 3170 \\
\hline $\mathrm{Ox}$ & 3254 & 3043 & 3164 & 2970 & 2955 & 2806 \\
\hline Calf & 2149 & 2844 & 2553 & 4663 & 4420 & 4580 \\
\hline Goat & 1650 & 1507 & 1449 & 2570 & 3247 & 2862 \\
\hline Pig & 4711 & 4885 & 4710 & 6120 & 5686 & 5805 \\
\hline Net change in inventory & 16347 & 17169 & 16637 & 19287 & 19383 & 19223 \\
\hline
\end{tabular}

Source: Authors' estimation, 2017-18 